$\begin{array}{rr}\text { JURNAL } & \text { Volume } 11, \text { Nomor } 4, \text { Agustus } 2015 \\ \text { FIT(1)PATOLOGI } & \text { Halaman } 105-112 \\ \text { I N D O NES I A } & \text { DOI: } 10.14692 / \text { jfi.11.4.105 } \\ \text { ISSN: } 0215-7950 & \end{array}$

\title{
Deteksi dan Identifikasi Dickeya sp. sebagai Organisme Pengganggu Tumbuhan Karantina A2 pada Tanaman Kentang di Jawa
}

\author{
Detection and Identification of Dickeya sp. as \\ A2 Quarantine Pest on Potato in Java
}

\author{
Haerani, Abdjad Asih Nawangsih*, Tri Asmira Damayanti \\ Institut Pertanian Bogor, Bogor 16680
}

\begin{abstract}
ABSTRAK
Erwinia chrysanthemi (saat ini Dickeya sp.) merupakan salah satu organisme pengganggu tumbuhan karantina (OPTK) A2 yang harus diwaspadai penyebarannya pada tanaman kentang di Indonesia. Tujuan penelitian ialah mendeteksi dan mengidentifikasi E. chrysanthemi pada tanaman kentang di Jawa. Sebanyak 400 sampel tanaman kentang yang menunjukkan gejala busuk lunak dan layu diambil dari beberapa daerah di Pangalengan dan Garut (Jawa Barat), Dieng (Jawa Tengah), dan Batu-Malang (Jawa Timur). Kejadian penyakit $E$. chrysanthemi ditentukan dengan Indirect-ELISA menggunakan antiserum poliklonal. Isolasi E. chrysanthemi dilakukan dari sampel positif ELISA. Karakterisasi isolat dilakukan dengan GEN III OmniLog ID System dan PCR. Primer spesifik Ec3F/Ec4R dan primer universal 16S rRNA, yaitu 27F/1429R, digunakan untuk menentukan sikuen DNA. Insidensi E. chrysanthemi mencapai $26.25 \%$ berdasarkan hasil ELISA. Bakteri dari sampel positif ELISA terdiri atas 37 isolat. Berdasarkan uji Gram, katalase, oksidase, dan oksidasi-fermentasi, 4 isolat bakteri diduga sebagai $E$. chrysanthemi. Hasil konfirmasi dengan Gen III OmniLog System, PCR, dan analisis gen 16S rRNA membuktikan tidak ada isolat bakteri yang teridentifikasi sebagai E. chrysanthemi. Sebaliknya, dengan pengujian tersebut diindentifikasi bakteri Pseudomonas oryzihabitans, Pantoea agglomerans, dan Pseudomonas viridiflava. Oleh karena E. chrysanthemi tidak dapat dikonfirmasi keberadaannya pada tanaman kentang di Jawa maka status OPTK A2 E. chrysanthemi pada tanaman kentang tidak terbukti dan diusulkan sebagai OPTK A1.
\end{abstract}

Kata kunci: Erwinia chrysanthemi, OmniLog, Pantoea agglomerans, Pseudomonas viridiflava

\begin{abstract}
Erwinia chrysanthemi (currently Dickeya sp.) is one of the A2 quarantine pest that must be concerned of its distribution on potato in Indonesia. The aim of this study is to detect and identify E. chrysanthemi from potato in Java. A total of 400 samples of potato plants showing symptoms of soft rot were obtained from several potato areas in Pangalengan and Garut (West Java), Dieng (Central Java), and BatuMalang (East Java). Disease incidence was determined by indirect enzyme-linked immunosorbent assay (I-ELISA) using polyclonal antiserum. E.chrysanthemi was isolated from plant samples with positive ELISA results. Furthermore, bacterial isolates were characterized by GEN III OmniLog ID System and PCR using specific primers Ec3F/Ec4R, as well as the universal 16S rRNA primer pair of 27F/1429R. The incidence of $E$. chrysanthemi based on ELISA was $26.25 \%$. From these samples, 37 bacterial isolates
\end{abstract}

\footnotetext{
*Alamat penulis korespondensi: Departemen Proteksi Tanaman, Fakultas Pertanian, Institut Pertanian Bogor, Jalan Kamper, Kampus Darmaga IPB, Bogor 16680

Tel: 0251-8629364, Faks: 0251-8629362, Surel: asnawangsih@yahoo.com
} 
was obtained. Based on physiological characters; Gram, catalase, oxidase, and oxidation-fermentation, there were 4 isolates similar to the genus of Erwinia. However, the results of Gen III OmniLog System, PCR, and nucleotide sequences analysis of $16 \mathrm{~S}$ rRNA confirmed that none of the isolates were identified as E.chrysanthemi. Otherwise, those 4 isolates were identified as Pseudomonas oryzihabitans, Pantoea agglomerans, and Pseudomonas viridiflava. The result of this study indicated that the existence of $E$. chrysanthemi as an A2 quarantine pest on potato in Java can not be confirmed and remains as an A1 quarantine pest.

Key words: Erwinia chrysanthemi, OmniLog, Pantoea agglomerans, Pseudomonas viridiflava

\section{PENDAHULUAN}

Produksi kentang di Indonesia masih rendah, yaitu hanya sekitar 16 ton $\mathrm{ha}^{-1}$ dibandingkan dengan di Eropa yang rataratanya mencapai sekitar 25.5 ton $\mathrm{ha}^{-1}$. Salah satu penyebab rendahnya produksi kentang ialah terbatasnya benih kentang berkualitas yang hanya sekitar $10 \%$ dari kebutuhan nasional; $4.9 \%$ di antaranya dipasok dari dalam negeri, sedangkan sisanya berasal dari impor (Baharuddin et al. 2012). Salah satu organisme pengganggu tumbuhan karantina (OPTK) penting yang banyak diperhatikan saat ini ialah Dickeya sp. (Erwinia chrysanthemi). Supriadi et al. (2002) melaporkan E. chrysanthemi sebagai penyebab pembusukan pada daun dan pangkal batang tanaman lidah buaya di Semplak, Bogor, Jawa Barat. E. chrysanthemi biovar 3 (sinonim dengan $D$. dadantii) ditemukan oleh Supriyanto et al. (2011) pada lahan gambut di Kalimantan Barat. Selain tanaman lidah buaya, E. chrysanthemi juga menyebabkan penyakit busuk lunak pada tanaman anggrek Phalaenopsis di DKI Jakarta dan Jawa Barat (Muharam et al. 2012). Beberapa laporan terkait identitas E. chrysanthemi di Indonesia mengarah pada $D$. dadantii dan masih didasarkan pada uji fisiologi dan biokimia, bukan berdasarkan uji molekuler.

Upaya untuk menelusuri kemungkinan masuk dan tersebarnya E. chrysanthemi ke wilayah Indonesia melalui umbi bibit kentang impor dapat dilakukan dengan mendeteksi keberadaan patogen tersebut di daerah yang diduga merupakan bagian dari daerah distribusi benih kentang impor.

\section{BAHAN DAN METODE}

\section{Pengambilan Sampel}

Sampel tanaman kentang diambil dari 4 lokasi pertanaman, yaitu Kecamatan Pangalengan, Jawa Barat dengan ketinggian 1459 m dpl (S 07 07' 06.6" E $\left.107^{\circ} 21^{\prime} 52.9^{\prime \prime}\right)$; Kecamatan Cikajang, Kabupaten Garut, Jawa Barat dengan ketinggian $1380 \mathrm{~m}$ dpl (S $7^{\circ}$ 14' 32.0" E $107^{\circ} 29^{\prime}$ 38.0"); kawasan Dieng Kecamatan Batur, Kabupaten Banjarnegara, Jawa Tengah dengan ketinggian $1400 \mathrm{~m}$ dpl (S 707' 15.1" E 109² 27' 38.0"); dan Kecamatan Bumiaji, Kota Batu, Malang, Jawa Timur dengan ketinggian $1656 \mathrm{~m}$ dpl (S 7²6' 57.7" E $\left.112^{\circ} 19^{\prime} 13.8^{\prime \prime}\right)$. Dari setiap lokasi diambil 100 tanaman yang menunjukkan gejala layu serta busuk lunak. Tanaman sakit ini berumur 50-90 hari setelah tanam (HST). Bagian tanaman yang diambil ialah pangkal batang dan umbi dan dideskripsikan gejalanya.

\section{Deteksi Serologi}

Sampel pangkal batang dan umbi tanaman kentang yang menunjukkan gejala khas layu dan busuk lunak dideteksi dengan indirect enzyme-linked immunosorbent assay (I-ELISA) menggunakan antiserum spesifik $E$. chrysanthemi (IgG Rabbit) dan conjugate Goat anti-Rabbit (IgG-AP) (Adgen). Dari setiap lokasi dibuat 20 sampel komposit (1 sampel komposit terdiri atas 5 sampel individual). Sampel komposit yang menunjukkan hasil positif ELISA selanjutnya diuji ulang secara individu untuk menentukan insidensi $E$. chrysanthemi. I-ELISA dilakukan sesuai dengan protokol yang dibuat oleh produsen antiserum. Intensitas warna pada hasil pengujian 
ELISA diukur menggunakan Thermo Scientific Multiscan ${ }^{\circledR}$ FC Microplate Photometer pada 60 menit setelah pemberian substrat. Uji dinyatakan positif jika nilai absorbansi ELISA (NAE) sampel uji $\geq 2$ kali NAE kontrol negatif (tanaman sehat).

\section{Isolasi dan Pemurnian Isolat}

Bakteri yang berasosiasi dengan sampel individu tanaman yang menunjukkan hasil positif E. chrysanthemi pada uji ELISA diisolasi menggunakan medium casamino acid peptone glucose (CPG) (Cuppels dan Kelman 1974). Potongan sampel direndam dalam akuades steril hingga keluar massa bakteri kemudian dihomogenkan. Suspensi bakteri diencerkan secara bertingkat, sebanyak $100 \mu \mathrm{L}$ dari masing-masing pengenceran ditumbuhkan pada medium CPG. Tahapan pemurnian isolat menggunakan medium nutrient agar (NA). Isolat murni bakteri yang diduga $E$. chrysanthemi disimpan dalam akuades steril untuk kemudian diidentifikasi dengan uji hipersensitivitas, karakter fisiologi, uji penggunaan sumber karbon dan polymerase chain reaction (PCR).

\section{Uji Hipersensitivitas}

Penyiapan suspensi bakteri untuk uji hipersensitif pada daun tembakau mengikuti prosedur De Boer dan Kelman (2001). Suspensi bakteri berumur 24 jam dengan kepadatan $10^{9} \mathrm{CFU} \mathrm{mL}^{-1}$ disuntikkan pada bagian bawah daun tembakau. Gejala hipersensitif berupa nekrotik atau klorosis pada daun tembakau diamati setelah 24-48 jam.

\section{Identifikasi Berdasarkan Karakter Fisiologi}

Karakter fisiologi yang diuji untuk Erwinia mengikuti Hyman et al. (2002), yaitu oksidase, katalase, dan oksidasi-fermentasi. Kemampuan menyebabkan busuk pada umbi kentang mengikuti De Boer dan Kelman (2001).

\section{Uji Penggunaan Sumber Karbon}

Isolat bakteri yang memiliki karakter fisiologi mirip dengan E. chrysanthemi diidentifikasi berdasarkan pada penggunaan sumber karbonnya menggunakan GEN III OmniLog ${ }^{\circledR}$ ID System (Biolog, Hayward, CA, USA) yang telah divalidasi oleh Sandle et al. (2013). E. chrysanthemi asal tanaman anggrek digunakan sebagai kontrol positif. Tahapan pengujian dilakukan sesuai dengan protokol yang dibuat oleh produsen GEN III OmniLog® ID System.

\section{Deteksi Asam Nukleat dengan PCR}

Deteksi asam nukleat dengan PCR dilakukan jika identifikasi berdasarkan uji fisiologi dan penggunaan sumber karbon menunjukkan hasil yang tidak sesuai dengan E. chrysanthemi. DNA bakteri diekstrak mengikuti metode Rahma (2013). Koloni bakteri diambil dengan ujung pipet tips dan dimasukkan ke dalam tabung mikro 1.5 $\mathrm{mL}$ yang berisi $100 \mu \mathrm{L} \mathrm{ddH}_{2} \mathrm{O}$. Suspensi bakteri dipanaskan 10 menit pada suhu $95{ }^{\circ} \mathrm{C}$ selama 1 menit. Selanjutnya suspensi bakteri tersebut menjadi cetakan untuk reaksi PCR. Kontrol positif uji ini menggunakan isolat $E$. chrysanthemi asal tanaman anggrek.

Amplifikasi DNA bakteri menggunakan primer spesifik E. chrysanthemi. Jika tidak teramplifikasi dengan primer spesifik maka deteksi DNA menggunakan primer universal 16S rRNA dan perunutan DNA. Reaksi PCR (total volume reaktan $25 \mu \mathrm{L}$ ) terdiri atas $12.5 \mu \mathrm{L}$ Dream Taq Green PCR master mix (Thermo Scientific), masing-masing sebanyak $1 \mu \mathrm{L}$ primer forward dan reverse $10 \mu \mathrm{M}, 1 \mu \mathrm{L}$ DNA templat, dan $9.5 \mu \mathrm{L}$ air bebas nuklease.

DNA bakteri diamplifikasi dengan sepasang primer spesifik E. chrysanthemi [Ec3F (5'-AAA TGC TGG C(T/C)G GTA TGC CGT A-3') dan Ec4R (5'-CAG CGT CAG GAA CGG ACA TAC-3')] dengan target amplikon berukuran $\sim 548$ pb dan program PCR sesuai yang digunakan Hseu et al. (2007). Amplifikasi DNA bakteri secara umum menggunakan primer universal $16 \mathrm{~S}$ rRNA dengan pasangan primer 27F (5'AGA GTT TGA TCM TGG CTC AG -3') dan 1429R (5'-CGG TTA CCT TGT TAC GAC TT -3') dan target amplikon berukuran $\sim 1500$ pb (Pradhap et al. 2011). 


\section{Perunutan DNA.}

Produk hasil PCR dikirim ke First Base, Malaysia untuk perunutan DNA sikuen. Sikuen gen 16S DNA dibandingkan dengan sikuen DNA bakteri yang sama dari negara lain yang terdeposit dalam GenBank menggunakan program basic local alignment search tool (BLAST) (www.ncbi.nlm.nih.gov). Homologi gen 16S DNA dilakukan menggunakan program ClustalW BioEdit yang dikalkulasi dengan pilihan "sequence identity matrix".

\section{HASIL}

\section{Gejala Layu dan Busuk Lunak}

Sampel tanaman kentang yang diambil dari lokasi penelitian di Pangalengan (Gambar 1a, e, dan i), Garut (Gambar 1b, f, dan j), Dieng (Gambar 1c, g, dan k), dan Malang (Gambar 1d, h, dan 1) pada umumnya menunjukkan gejala khas layu dan busuk lunak.

\section{Insidensi $E$. chrysanthemi berdasarkan ELISA}

Frekuensi sampel tanaman kentang yang menunjukkan positif E. chrysanthemi berdasarkan hasil ELISA sebesar 26.25\%, yaitu sebanyak 105 dari 400 sampel uji. Frekuensi sampel yang menunjukkan reaksi ELISA positif untuk E. chrysanthemi di Pangalengan, Garut, Malang, dan Dieng berturut-turut ialah 3, 1, 3, dan 98\%. Sebanyak 37 isolat berhasil diisolasi dari 10 sampel tanaman positif ELISA.

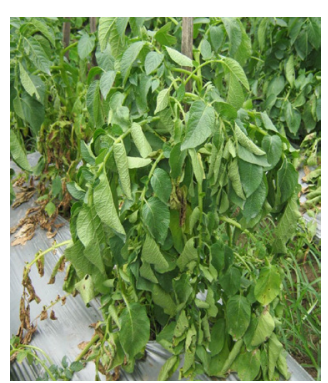

a

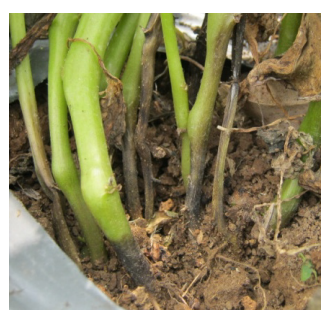

e

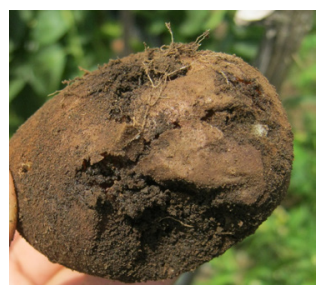

i

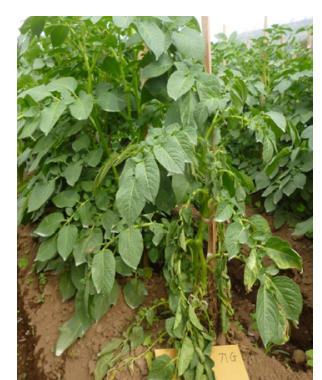

b

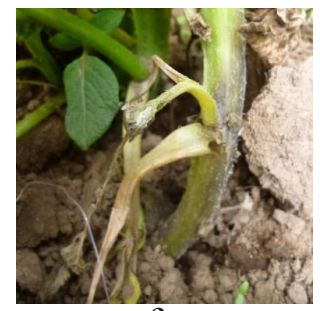

$\mathrm{f}$

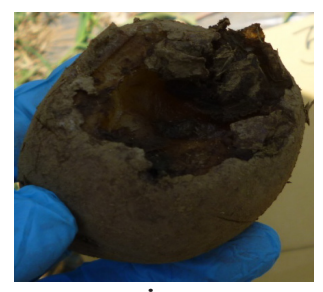

j

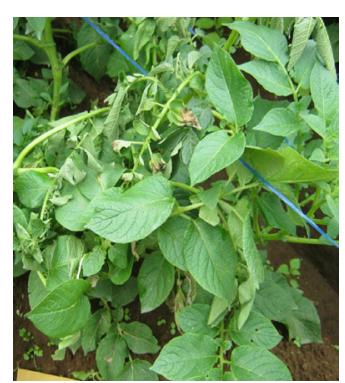

c

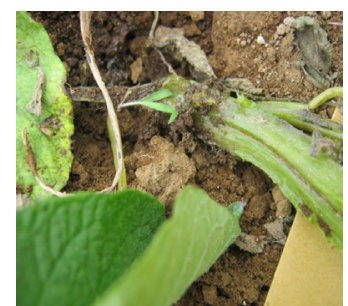

$\mathrm{g}$

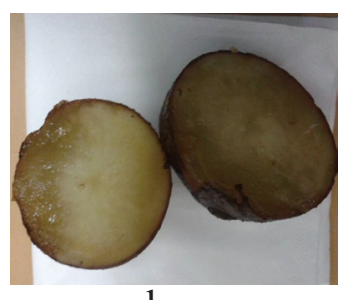

$\mathrm{k}$

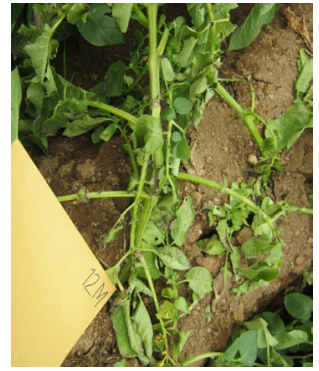

d

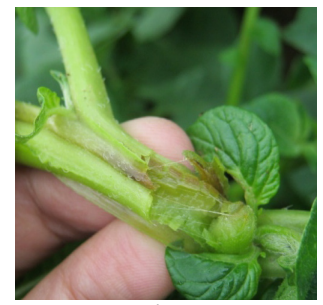

$\mathrm{h}$

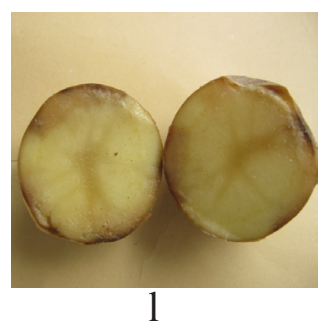

Gambar 1 Gejala layu dan busuk lunak pada kentang. a, daun tanaman yang layu menggulung ke atas (Pangalengan); b, tanaman layu kemudian mengering mulai di bagian tepi daun (Garut); c, tanaman yang layu pertumbuhannya terhambat (Dieng); d, tanaman yang layu terlihat rebah (Malang); e, pangkal batang kehitaman dan mengecil (Pangalengan); f, batang kehitaman dan lunak (Garut); g dan h, batang busuk basah berturut-turut di Dieng dan Malang; i dan j, umbi membusuk berturut-turut di Pangalengan dan Garut; $\mathrm{k}$ dan 1, umbi tidak menunjukkan gejala busuk, akan tetapi setelah dibelah bagian dalam terlihat berair dan lunak berturut-turut di Dieng dan Malang. 


\section{Uji Hipersensitivitas}

Sebanyak 18 dari 37 isolat menunjukkan gejala lesio lokal nekrosis pada tanaman tembakau (Tabel 1). Hanya isolat 14M-6 yang menghasilkan nekrosis setelah 24 jam, sama dengan isolat positif $E$. chrysanthemi dari anggrek. Isolat 35P-3, 96P-2, 12M-1, 12M-2, $12 \mathrm{M}-3$, 12M-4, dan 14M-9 menimbulkan nekrosis setelah 48 jam, sedangkan isolat 35P-1, 35P-5, 49P-5, 71G-1, 71G-6, 3D-2, 3D-3, 23D-2, 23D-3, dan 44D- menimbulkan gejala klorosis setelah 48 jam. Selanjutnya 18 isolat tersebut diuji karakter fisiologinya.

\section{Karakter Fisiologi Isolat}

Berdasarkan hasil uji Gram, katalase, oksidase, oksidasi-fermentasi, dan kemampuan menyebabkan busuk pada umbi kentang terdapat 4 isolat yang memiliki karakter fisiologi mirip dengan genus Erwinia, yaitu isolat 49P-5, 71G-1, 71G-6, dan 14M-6 (Tabel 1). Empat isolat tersebut menunjukkan reaksi Gram negatif, katalase positif, oksidase negatif dan dapat memfermentasikan glukosa serta menyebabkan busuk pada umbi kentang. Kemampuan menyebabkan busuk pada umbi kentang seperti pada isolat kontrol positif, hanya ditunjukkan oleh isolat 14M-6, sedangkan isolat 49P-5, 71G-1, dan 71G-6 menyebabkan basah pada daerah yang diinokulasi.

\section{Identifikasi Berdasarkan Pemanfaatan Sumber Karbon}

Berdasarkan uji pemanfaatan sumber karbon menggunakan GEN III OmniLog System, 4 macam isolat yang diidentifikasi, yaitu Flavimonas oryzihabitan, Pantoea dispersa, P. agglomerans, dan Pseudomonas syringae pv. primulae (Tabel 2). Identifikasi berdasarkan pemanfaatan sumber karbon ini, tidak ada satu pun yang teridentifikasi sebagai E. chrysanthemi, walaupun ciri-ciri fisiologi menunjukkan genus Erwinia. Hasil identifikasi ini perlu dikonfirmasi dengan deteksi DNA melalui PCR dan perunutan DNA gen 16S rRNA karena identifikasi dengan GEN III

Tabel 1 Uji hipersensitivitas pada tanaman tembakau dan uji fisiologi isolat bakteri asal tanaman kentang dari beberapa sentra pertanaman di Jawa

\begin{tabular}{lcccccc}
\hline \multirow{2}{*}{ Isolat bakteri } & $\begin{array}{c}\text { Reaksi } \\
\text { hipersensitif }\end{array}$ & Gram & Katalase & Oksidase & O/F & $\begin{array}{c}\text { Pembusukan } \\
\text { umbi kentang }\end{array}$ \\
\cline { 3 - 7 } & (k) 48 jam & + & + & - & $+/+$ & - \\
$35 \mathrm{P}-1$ & (n) 48 jam & - & - & - & $+/+$ & - \\
$35 \mathrm{P}-3$ & (k) 48 jam & - & + & + & $+/+$ & - \\
$49 \mathrm{P}-5$ & (k) 48 jam & - & + & - & $+/+$ & $>24$ jam \\
$96 \mathrm{P}-2$ & (n) 48 jm & - & + & - & $+/+$ & - \\
$71 \mathrm{G}-1$ & (k) 48 jam & - & + & - & $+/+$ & $>24$ jam \\
$71 \mathrm{G}-6$ & (k) 48 jam & - & + & - & $+/+$ & $>24$ jam \\
$3 \mathrm{D}-2$ & (k) 48 jam & - & + & - & $+/+$ & - \\
$3 \mathrm{D}-3$ & (k) 48 jam & - & + & - & $+/+$ & - \\
$23 \mathrm{D}-2$ & (k) 48 jam & + & - & - & $+/-$ & - \\
$23 \mathrm{D}-3$ & (k) 48 jam & + & - & - & $+/-$ & - \\
$44 \mathrm{D}-1$ & (k) 48 jam & - & + & - & $+/+$ & - \\
$12 \mathrm{M}-1$ & (n) 48 jam & - & + & + & $+/+$ & - \\
$12 \mathrm{M}-2$ & (n) 48 jam & - & + & + & $+/+$ & - \\
$12 \mathrm{M}-3$ & (n) 48 jam & - & + & + & $+/+$ & - \\
$12 \mathrm{M}-4$ & (n) 48 jam & - & + & + & $+/+$ & - \\
$14 \mathrm{M}-6$ & (n) 24 jam & - & + & - & $+/+$ & 24 jam \\
$14 \mathrm{M}-9$ & (n) 48 jam & - & - & + & $+/-$ & - \\
K $(+)^{2}$ & (n) 24 jam & - & + & - & $+/+$ & $<24$ jam \\
\hline
\end{tabular}

1(k), gejala klorosis; (n), gejala nekrotik

${ }^{2}$ Erwinia chrysanthemi asal anggrek 
OmniLog System terbatas pada spesies yang ada dalam basis data.

\section{Identifikasi Bakteri Berdasarkan Sikuen 16S DNA}

Hasil amplifikasi menggunakan primer spesifik Ec3F/Ec4R terhadap 4 isolat bakteri yang memiliki karakter fisiologi mirip $E$. chrysanthemi tidak menghasilkan amplikon berukuran $548 \mathrm{pb}$ yang merupakan target untuk E. chrysanthemi. Dengan demikian, identitas 4 isolat bakteri yang diuji bukan E. chrysanthemi. Hasil deteksi gen 16S rDNA dari keempat isolat dan runutan sikuennya, diketahui ukuran gen $16 \mathrm{~S}$ rDNA yang dapat diamplifikasi ialah $\pm 1500 \mathrm{pb}$ (Gambar 2). Berdasarkan perunutan DNA, isolat 49P-5 adalah Pseudomonas oryzihabitans, isolat 71G-1 dan 71G-6 adalah Pantoea agglomerans, dan isolat 14M-6 adalah Pseudomonas viridiflava (Tabel 3). Tidak ada isolat yang teridentifikasi sebagai E. chrysanthemi.

\section{PEMBAHASAN}

Hasil uji serologi mengindikasikan bahwa $E$. chrysanthemi terdeteksi pada sampel tanaman kentang yang diuji, tetapi uji GEN III Omnilog System, PCR dan analisis gen 16S rRNA tidak mendeteksi adanya E. chrysanthemi. Hal ini menunjukkan antiserum poliklonal E. chrysanthemi yang digunakan bersifat tidak spesifik karena antiserum poliklonal mengenali lebih dari 1 epitop (Emantoko 2001). Oleh karena itu, deteksi serologi bakteri dengan antiserum poliklonal bermanfaat hanya untuk penapisan awal bakteri target. Hasil penelitian ini menunjukkan penggunaan antiserum poliklonal menimbulkan reaksi silang dengan bakteri lain; antiserum dapat mendeteksi bakteri dari genus dan atau bahkan spesies lain.

Identifikasi menggunakan GEN III Omnilog System sangat praktis, cepat, serta dapat langsung mengidentifikasi isolat yang

Tabel 2 Hasil identifikasi isolat bakteri asal tanaman kentang berdasarkan uji pemanfaatan sumber karbon dengan GenIII Omnilog System.

\begin{tabular}{llccc}
\hline Isolat bakteri & \multicolumn{1}{c}{ Spesies } & PROB $^{\mathrm{a}}$ & SIM $^{\mathrm{b}}$ & DIST $^{\mathrm{c}}$ \\
\hline 49P-5 & Flavimonas oryzihabitans & 0.646 & 0.646 & 5.161 \\
$71 \mathrm{G}-1$ & Pantoea dispersa & 0.847 & 0.641 & 3.410 \\
$71 \mathrm{G}-6$ & Pantoea agglomerans & 0.740 & 0.548 & 3.621 \\
$14 \mathrm{M}-6$ & Pseudomonas syringae pv. primulae & 0.582 & 0.582 & 6.115 \\
\hline
\end{tabular}

apROB, probability; ' ${ }^{\mathrm{b}} \mathrm{SIM}$, similarity; ${ }^{\mathrm{c} D I S T}$, distance

Nilai PROB dan SIM berkisar 0-1, nilai DIST berkisar 0-10 (jika $>10$ maka isolat yang diuji tidak dapat teridentifikasi).

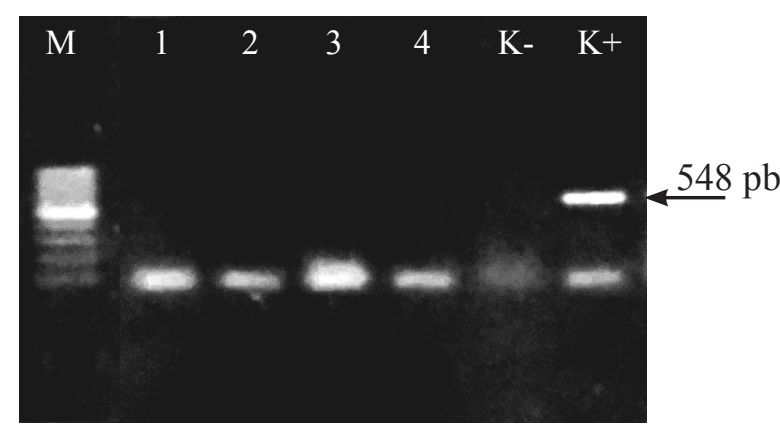

a

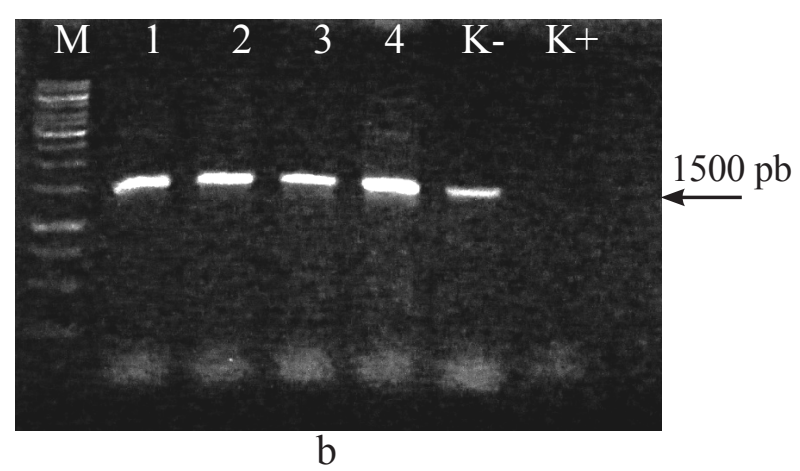

$\mathrm{b}$

Gambar 2 Visualisasi pita DNA isolat bakteri hasil amplifikasi menggunakan a, primer spesifik Ec3F/Ec4R dengan M, 100 pb dan; b, primer universal 16S rRNA dengan M, $1 \mathrm{~Kb}$. M, penanda DNA (Thermo Scientific); 1, isolat 49P-5; 2, isolat 71G-1; 3, isolat 71G-6; 4, isolat 14M-6; K+, kontrol positif; K-, kontrol negatif. 
Tabel 3 Homologi basa nukleotida 16S rRNA isolat bakteri asal tanaman kentang

\begin{tabular}{llccccc}
\hline $\begin{array}{l}\text { Isolat } \\
\text { bakteri }\end{array}$ & Spesies & $\begin{array}{c}\text { Panjang DNA } \\
(\mathrm{pb})\end{array}$ & $\begin{array}{c}\text { Homologi } \\
(\%)\end{array}$ & $\begin{array}{c}\text { Tanaman } \\
\text { Inang }\end{array}$ & Asal & $\begin{array}{c}\text { No. Aksesi } \\
\text { Genbank }\end{array}$ \\
\hline $49 \mathrm{P}-5$ & $\begin{array}{l}\text { Pseudomonas } \\
\text { oryzihabitans }\end{array}$ & 1435 & 98 & Tembakau & Cina & JX067903.1 \\
$71 \mathrm{G}-1$ & $\begin{array}{l}\text { Pantoea } \\
\text { agglomerans }\end{array}$ & 1567 & 92 & Bambu & India & FR872702.1 \\
$71 \mathrm{G}-6$ & $\begin{array}{l}\text { Pantoea } \\
\text { agglomerans }\end{array}$ & 1446 & 85 & Rumput & Finlandia & KJ529102.1 \\
$14 \mathrm{M}-6$ & $\begin{array}{l}\text { Pseudomonas } \\
\text { viridiflava }\end{array}$ & 97 & Kapri & Spanyol & GQ398129.1 \\
\hline
\end{tabular}

diuji, namun metode ini memiliki kelemahan karena mikroorganisme yang ada pada basis data GEN III Omnilog System terbatas. Target pengujian yang belum tercatat dalam basis data, hasil identifikasinya menjadi kurang akurat.

Deteksi asam nukleat dengan PCR dan atau perunutan DNA dilakukan untuk mengatasi kelemahan deteksi serologi dengan antiserum poliklonal (Sudrajat et al. 2000). Seleksi awal bakteri target dapat dilakukan dengan uji serologi, kemudian dikombinasikan dengan deteksi asam nukleat pada sampel dengan NAE paling tinggi di antara sampel lainnya. Adapun ditemukannya produk dimer pada hasil PCR kemungkinan disebabkan oleh konsentrasi primer yang terlalu tinggi sehingga menghasilkan produk yang tidak spesifik (Brownie et al. 1997).

Hasil penelitian ini menunjukkan bahwa pada sentra produksi kentang di Pangalengan, Garut, Dieng dan Malang ditemukan indikasi adanya E. chrysanthemi berdasarkan analisis ELISA, akan tetapi setelah dikonfirmasi uji PCR menggunakan primer spesifik E. chrysanthemi hasilnya negatif. Dengan demikian, status OPTK A2 E. chrysanthemi pada tanaman kentang masih belum dapat dibuktikan sehingga tetap perlu diwaspadai keberadaannya. Hasil penelitian ini juga mendukung langkah Badan Karantina Pertanian yang mengusulkan peningkatan status E. chrysanthemi menjadi OPTK A 1 dan diperbaharui nama identitasnya sesuai penamaan terbaru menjadi Dickeya spp. berdasarkan Samson et al. (2005) dan Toth et al. (2011) yang telah melaporkan tujuh spesies Dickeya: D. chrysanthemi, D. dadantii, D. dianthicola, D. dieffenbachiae, D. paradisiaca, D. solani, dan D. zeae.

Selain itu, Badan Karantina Pertanian perlu meningkatkan kewaspadaan terkait ditemukannya OPTKA1 Pantoea agglomerans dan Pseudomonas viridiflava, walaupun hasil temuan ini masih harus dikonfirmasi dengan deteksi PCR menggunakan primer spesifik. Selain itu perlu dipastikan juga sifat 2 spesies bakteri tersebut dengan melakukan uji patogenisitas pada tanaman inangnya.

\section{UCAPAN TERIMA KASIH}

Ucapan terima kasih disampaikan kepada Balai Besar Karantina Pertanian Tanjung Priok atas dukungan berupa fasilitas penelitian, serta Giyanto dan Refa Firgianto atas bantuan isolat kontrol positif E. chrysanthemi.

\section{DAFTAR PUSTAKA}

Baharuddin, Kuswinanti T, Lamba SE. 2012. Percepatan Ketersediaan Benih Kentang Unggulan Melalui Introduksi Paket Bioteknologi Ramah Lingkungan di Kabupaten Toraja Utara. Di dalam: Prosiding InSINas; 2012 Nov 29-30; Bogor (ID): Institut Pertanian Bogor. hlm 336-344. Brownie J, Shawcross S, Theaker J, Whitcombe D, Ferrie R, Newton C, Little S. 1997. The elimination of primer-dimer accumulation in PCR. Nucl Acids Res. 25(16):32353241. DOI: http://dx.doi.org/10.1093/ nar/25.16.3235. 
Cuppels D, Kelman A. 1974. Evaluation of selective medium for isolation of soft rot bacteria from soil and plant tissue. Phytopathology. 64:468-475. DOI: http:// dx.doi.org/10.1094/Phyto-64-468.

De Boer, Kelman. 2001. Gram negative bacteria: Erwinia soft rot group. Di dalam: Schaad NW, Jones JB, Chun W, editor. Laboratory Guide for Identification of Plant Pathogenic Bacteria. $3^{\text {rd }}$ edition. New York (US): APS Pr. hlm 56-72.

Emantoko S. 2001. Antibodi rekombinan: perkembangan terbaru dalam teknologi antibodi. Unitas. 9(2):29-43.

Hseu SH, Shentue HI, Tzeng KC, Lin CY. 2007. Development of specific primers for differential identification pathogen Erwinia carotovora subsp. caratovora and Erwinia chrysanthemi. Plant Pathol Bull. 16:19-29.

Hyman LJ, Toth IK, Pérombelon MCM. 2002. Isolation and identification. Di dalam: Perombelon MCM, Van Der Wolf $\mathrm{J} \mathrm{M}$, editor. Methods for the detection and quantification of Erwinia carotovora subsp. atroseptica (Pectobacterium carotovorum subsp. atrosepticum) on potatoes: a laboratory manual. Dunde (UK): Scottish Crop Research Institute Occasional Publication No. 10. hlm 66-71.

Muharam A, Indrasti R, Hanudin. 2012. Occurrence of Dickeya dadantii the causal agent of bacterial soft rot on orchids in DKI Jakarta and West Java Indonesia. Crop Environ. 3(1-2):37-44.

Pradhap M, Selvisabhanayakam, Mathvianan V, Parthasarathy, Ayyapan JVAA, Kumar SS. 2011. Study on 16S rRNA based PCR method for spesific detection of Salmonella entrica typhi from gut of infected silkworm Bombyx mori (Linn.). J Sci Ind Res. 70:909-911.

Rahma H. 2013. Penyakit layu stewart (Pantoea stewartii subsp. stewartii) pada jagung dan upaya pengendaliannya [disertasi]. Bogor (ID): Institut Pertanian Bogor.
Samson R, Legendre JB, Christen R, FischerLe SauxM, Achouak W, Gardan L, 2005. Transfer of Pectobacterium chrysanthemi (Burkholder et al., 1953) Brenner I. 1973 and Brenneria paradisiaca to the genus Dickeya gen. nov. as Dickeya chrysanthemi comb. nov and Dickeya paradisiaca comb. nov. and delineation of four novel species, Dickeya dadantii sp. nov., Dickeya dianthicola sp. nov., Dickeya dieffenbachiae sp. nov. and Dickeya zeae sp. nov. Int J Syst Evol Microbiol. 55: 1415-27. DOI: http:// dx.doi.org/10.1099/ijs.0.02791-0.

Sandle T, Skinner K, Sandle J, Gebala B, Kothandaraman P. 2013. Evaluation of the GEN III OmniLog® ID system microbial identification system for the profiling of clean room bacteria. Eur Parenter Pharmaceut Sci. 18(2):1-7.

Sudrajat D, Maria LR, Suhadi F. 2000. Deteksi cepat bakteri Escherichia coli enterohemoragik (EHEK) dengan metode PCR (Polymerase Chain Reaction). Risalah Pertemuan Ilmiah Penelitian dan Pengembangan Teknologi Isotop dan Radiasi. 75-80.

Supriadi, Ibrahim N, Taryono. 2002. Karakterisasi Erwinia chrysanthemi penyebab penyakit busuk bakteri pada daun lidah buaya (Aloe vera). J Litri. 8(2):45-48. Supriyanto, Priyatmojo A, Arwiyanto T. 2011. Uji penggabungan PGPF dan Pseudomonas putida strain Pf-20 dalam pengendalian hayati penyakit busuk lunak lidah buaya di tanah gambut. J HPT Trop. 11:11-21.

Toth IK, van der Wolf JM, Saddler G, Lojkowska E, He' lias V, Pirhonen M, Tsror (Lahkim) L, Elphinstone JG. 2011. Dickeya species: an emerging problem for potato production in Europe (review). Plant Pathol. 1-15. DOI: http://dx.doi.org/10.111 1/j.1365-3059.2011.02427. 